\title{
Effect of ice gel compress towards labor pain during Active Phase Stage I at private midwivery clinics in Surabaya City area
}

\author{
Nova Elok Mardliyana', Abkar Raden², Umu Hani EN² \\ 'Faculty of Health Sciences, Muhammadiyah University, Surabaya, ${ }^{2}$ Faculty of Health Sciences, \\ Aisyiyah University, Yogyakarta
}

\begin{abstract}
ABSTRAK
Tujuan: menjelaskan pengaruh pemberian kompres ice gel terhadap nyeri persalinan kala I fase aktif

Bahan dan Metode: Rancangan penelitian True experiment dengan desain Randomized Controlled Trial dilakukan di beberapa tempat bidan praktik mandiri. Sampel penelitian ibu bersalin sebanyak 44 dimana 22 ibu bersalin yang diberikan kompres ice gel dan $22 \mathrm{ibu}$ bersalin dilakukan tehnik relaksasi. Analisis yang digunakan meliputi uji statistik chi-square dengan confidence interval $95 \%$.

Hasil: Hasil penelitian menunjukkan ada hubungan yang signifikan antara pemberian kompres ice gel dengan penurunan intensitas nyeri persalinan kala I fase aktif dengan nilai $p$ value 0,000 dan confidence interval : 2,1-18,3.

Simpulan: Ibu bersalin yang diberikan kompres ice gel mengalami nyeri lebih rendah dibandingkan yang tidak diberikan kompres ice gel. (MOG 2017;25:21-24)
\end{abstract}

Kata kunci: Kompres Ice Gel; nyeri persalinan; kala I fase aktif

\begin{abstract}
Objectives: to clarify the effect of gel ice pack against the first stage of labor pain of the active phase.

Materials and Methods: The study design True experiment with design Randomized Controlled Trial conducted in several places independently practicing midwives. Research samples were 44 maternal maternity which 22 were given ice gel packs and 22 maternal performed relaxation techniques. The analysis includes statistical chi-square test with $95 \%$ confidence interval.

Results: The results showed no significant correlation between the administration of gel ice packs to decrease pain intensity active phase of the first stage of labor with $p$ value of 0.000 and a confidence interval: 2.1 to 18.3 .

Conclusion: Mother maternity given gel ice packs experienced lower pain than those not given the gel ice pack. (MOG 2017;25: 21-24)
\end{abstract}

Keywords: Compress Ice Gel; labor pain; active phase stage I

Correspondence: Nova Elok Mardliyana. Faculty of Health Sciences, Muhammadiyah University, Surabaya.

Email : novaelok@fik.um-surabaya.ac.id

\section{INTRODUCTION}

Childbirth is the process of delivering the baby, placenta and amniotic membranes out from the uterus. A normal delivery occurs if the gestational age is sufficient enough (after 37 weeks) and no complication is undergone. The birth proces, which is identical to the pain, can make a frightening experience. Labor pain occurs because the uterine muscles contract, since the fetal head moves through the birth canal causing pressure on the bladder, rectum, spine and pubic bone ${ }^{19}$.

The pain of labor is unique and it is a natural process felt by the mother who will give birth to a baby. Handling labor's pain, especially in the first stage of the active phase, is very important, because when the pain of labor is not handled, the mother will feel a severe pain, which will lead to anxiety or fear and end up with panic $^{15}$. Prolonged labor pain can also lead to hyperventilation and will slow down the deceleration of fetal heart beat. This condition stimulates an increase in catecholamine level, that will cause a disturbance of uterine contractions and result in uterine inertia. If this condition is not treated well, it will cause an old partus, affect mothers and fetuses' condition, and in the end can increase cesarean section (CS) interventions by $22.7 \%{ }^{12}$

The World Health Organization (WHO) has limited the SC percentage for each country, which is $5-15 \%$ labor. If the $\mathrm{SC}$ is not performed as indicated, it will increase the risk of maternal and infant morbidity and mortality ${ }^{20}$. Based on the report of Riskesdas in 2013, CS percentage in Indonesia is $9.8 \%$, while in East Java is $10.3 \%{ }^{13}$. Maria's research (2011) shows that the number of CS done with indication at Dinas Kesehatan Tentara Hospital (DKT) Hospital Surabaya was 58,17\%, while the number of CS without indication was as much as $41.83 \%$. The percentage of primipara parity who undergo CS without indication is as much as $65,19 \%$. This happens because of the fear and anxiety of moms in facing the pain for a long time and the damage to the birth canal as a result of normal childbirth which moms don't want to experience ${ }^{13}$.

Bad labor pain can cause anxiety in the mother, especially primipara. Currently there is still very limited action done to reduce the pain in primiparas, which eventually will lead to prolonged labor and fatigue of mother during labor. Mother will have bad experience 
that can cause problems, both physically and psychologically, such as guilty or discouraged feeling, anxious, panic, emotional control ability loss, which will results in decreased personality quality, anger to the baby, and decreased sexual response (fear of being pregnant again), and will also results guilty feeling in husbands for failing to help their wives.

One of the methods that can be used is non-pharmacological methods in pain management, since they can reduce pain without any potential to cause harmful effects for mother and baby. Beside its ability to reduce pain, some non-pharmacological techniques also have non-invasive, simple, effective, and no harmful effects ${ }^{4}$. Those non-pharmachological techniques are relaxation techniques, acupressure, water therapy, music therapy, hot or cold compresses, massage and touch, which are more desirable than pharmacological methods ${ }^{12}$.

Cold compress is one of the non-pharmacological method that is considered very effective in reducing pain. Cold compress is an ice therapy that can cause vasoconstriction in the area of pain, and the body will attempt to remove heat5. Cold compresses can reduce blood flow to a part and reduce the bleeding of edema that is thought to cause analgesic effects, by slowing the speed of nerve conduction, so that fewer pain impulse will reach the brain ${ }^{18}$.

Some types of tools that can be used for cold compresses are such as ice-filled rubber gloves, icesoaked towels, and ice gel ${ }^{19,5}$. Ice gel is a pack containing hypoallergenic gel that can be used for cold or hot. If it is used for cold compress, ice gel can be maintained longer outside the freezer compared to regular ice. Ice gel is reusable and easy to obtain because it is available in pharmacies. In general, ice gel can be used for 15 to 20 minutes. On the plastic packaged ice gel, towel is required to dry water condensates ${ }^{20}$.

A study on the effects of ice pack in the labor pain relief in Iran showed that the application of ice pack on mother's back and belly can reduce pain during the active phase first stage and the application of ice pack on mother's perineum can significantly reduce the pain of second stage without giving side effects on mother and fetus ${ }^{11}$. Methods of reducing labor pain need to be developed through research in health service especially in midwifery service in Indonesia to explore the benefits and to prove its influence scientifically, so that labor pain can be done without pharmacological way. Based on the those backgrounds, researchers are interested to know the influence of ice gel compress on the reduction of labor pain in primipara.

\section{MATERIALS AND METHODS}

This research use true experiment method, with Randomized Controlled Trial design. In this research, sampling is done randomy to create same characteristics between groups. ${ }^{6}$ The dependent variable in this research is labor pain of active phase stage I, independent variable is ice gel compress, and confounding variable is the preparation of labor.

The populations of this research are mothers giving birth at Private Midwivery Clinics Hj.Farida Hajri, S.ST, Maulina Hasnida, S.ST, Evi Kusumawati, AMd.Keb and Mu'arofah, AMd.Keb in Surabaya. The samples in this study are mothers in the populations that meet the inclusion and exclusion criteria. Inclusion criterias: Active stage of inpartu, (4-7 cm wide opening), normal pregnancy, nullipara or primipara, term, maternal age of 20-35 years old, willing to be a labor mother, accompanied by close family during delivery, do not have disabilities such as deafness, blindness, speech impairment and mental disorders. Exclusion criteria: Uncooperative maternal mothers and mothers with cold allergies.

The sampling technique in this research was done randomly (random) or called probability sampling with simple random sampling technique. The samples of 44 maternal women were divided into two groups, the intervention group was given ice gel compress $(n=22)$ and the control group was not given ice gel compress but still got standard treatment such as relaxation technique $(\mathrm{n}=22)$.

Intervention given in this research was giving ice gel compression. Ice gel used in this research was local ice gel production with non-toxic material. Ice gel used medium size was $14 \times 9 \times 2 \mathrm{~cm}$ with temperature of $\leq$ $10^{\circ} \mathrm{C}$. Ice gel had been frozen in the freezer for 8 hours. The application method was by compressing the lower back precisely at L1-L5 and the lower abdomen precisely at the suprasymphisis for 10 minutes with ice gel in the time of contraction and the patients were positioned tilting to the left. Measurement of pain was done with NRS (Numeric Rating Scale), which was performed before and after intervention. The control group was only given deep breath relaxation guidance. Both groups continued to receive normal birth attendance and were accompanied by their closest family.

Chairman of the research ethics committee LP3M University 'Aisyiyah Yogyakarta stated that this study was approved to be implemented, the approval is set on 21 October 2016 with the number: 03/KEP-UNISA/X/ 2016. 
The weaknesses of this study were that the ice gel should be stored in a freezer or cooler box to keep the temperature cool, cannot be used in patients with cold allergies and can cause frosbite (freezing some organs exposed to excessive cold temperatures) if the use of ice gel compresses is too long and continuous for $>20$ minutes.

Analysis used in this research was univariate analysis, bivariate analysis using statistical calculation with Chi Square (X2) formula ${ }^{6}$.

\section{RESULTS AND DISCUSSION}

Table 1. Frequency distribution of samples' characteristics at private midwivery clinic in surabaya city area

\begin{tabular}{lcccc}
\hline \multicolumn{1}{c}{ Variables } & $\begin{array}{c}\text { Intervention Group } \\
(\mathrm{n}=22)\end{array}$ & $\begin{array}{c}\text { Control Group } \\
(\mathrm{n}=22)\end{array}$ & \\
& $\mathrm{N}$ & $\%$ & $\mathrm{~N}$ & $\%$ \\
\hline Pain intensity & & & & \\
Moderate & 19 & 86 & 3 & 14 \\
Severe & 3 & 14 & 19 & 86 \\
\hline Labor Preparation & & & & \\
Follow & 4 & 18 & 3 & 14 \\
Did not follow & 18 & 82 & 19 & 86 \\
\hline
\end{tabular}

Table 1 shows that the highest percentage of pain intensity in the intervention group was moderate pain $(86 \%)$ while the control group experienced severe pain $(86 \%)$. The percentage of samples in the intervention group who followed labor preparation was $82 \%$ and the control group was $86 \%$.

Table 2. Chi square test between intervention group (ice gel compress) and control group to-wards the labor pain during active phase stage $i$ at private midwivery clinic in Surabaya City Area

\begin{tabular}{|c|c|c|c|c|c|c|c|}
\hline \multirow{3}{*}{$\begin{array}{l}\text { Variables } \\
\text { Ice Gel } \\
\text { Compress }\end{array}$} & \multicolumn{4}{|c|}{ Labor Pain } & \multirow[t]{3}{*}{$\mathrm{N}$} & \multirow[t]{3}{*}{$\mathrm{RR}$} & \multirow[t]{3}{*}{$P$ value } \\
\hline & \multicolumn{2}{|c|}{ Moderate } & \multicolumn{2}{|c|}{ Severe } & & & \\
\hline & $\mathrm{n}$ & $\%$ & $\mathrm{n}$ & $\%$ & & & \\
\hline Yes & 19 & 86 & 3 & 14 & 22 & 6 & 0,000 \\
\hline No & 3 & 14 & $\begin{array}{l}1 \\
9\end{array}$ & 86 & 22 & & $\begin{array}{l}\text { (CI : } 2,1 \\
-18,3)\end{array}$ \\
\hline
\end{tabular}

Table 2 shows the statistical test result which obtained p-value of 0.000 which means that there is a significant relationship between the treatment of ice gel compress with labor pain. The analysis result also showed $\mathrm{RR}=6$ (95\% CI: 2,1-18,3) which mean that maternal mother given ice gel compress had 6 times chance to experience moderate pain compared to maternal mother not given ice gel compress.
This study shows that ice gel compress has a significant relationship in reducing labor pain. Based on statistical test results, the $\mathrm{p}$ value is 0.000 , which is $<0,05$. The result got $\mathrm{RR}$ value of $6(95 \%$ CI $2,1-18,3)$ which means that there is a relation between applying ice gel compress and decreasing of labor pain significantly, and therefore the hypothesis is accepted. Mothers who were given ice gel compresse were 6 times more likely to experience moderate pain than those who were not given ice gel compresses.

The results of pain level analysis in the intervention group found that $86 \%$ mothers in this group experienced moderate pain level and 14\% experienced severe pain. This is in accordance with the study's result done by Angela Baker (2001) which found out that there are women who give birth to moderate and in severe pain ${ }^{3}$. This study was carried out in the active phase with the cervical opening of $4-7 \mathrm{~cm}$, where the greater the cervical opening is, the more severe the pain will be. In addition, the cultural and ethnical background or maternal races' influences towards the perception and expression of labor pain were not examined.

Ice gel compresses can reduce labor pain during the active phase stage I. This is in accordance with research conducted by Shirvani \& Ganji, 2013 which stated that giving ice gel compresses can reduce labor pain during the active phase stage I. Ice gel compress is a cold compress action using a gel-shaped tool packaged in neutralized and non-toxic plastic bags ${ }^{17}$. Ice gel can be used as a non-pharmacological method in the reduction of labor pain ${ }^{19}$, because ice gel can keep cold temperatures longer (up to 48 hours), non-aqueous as ice, safe and non-toxic, as well as effective, efficient and very economical as it can be used repeatedly, so that midwives can provide labor pain reduction in delivery care $^{7}$.

Cold compresses using ice gel can absorb the calories of the local area of labor pain resulting in temperature decrease. Neurohormonal response to ice gel compresses is the release of endorphin, decreased sensory nerve transmission, decreased activity of nerve cell body, and decreased irritant which is cell metabolism waste ${ }^{2}$. Giving ice gel compress is also one of the way to give stimulation to skin. This stimulation sends impulses from the periphery to the hypothalamus which then can become a normal body temperature sensation ${ }^{17}$. Ice gel compresses can also block pain transmission to the cerebral cortex because the cold stimulation reaches the brain first.

A research was conducted by Nagwa Abdel Fadeel Abd El Hamid (2015) to study the effects of giving ice 
massage and acupressure to labor pain and labor duration. Both actions can both reduce labor pain and shorten the labor time of stage I and II by giving intervention to be repeated every 30 minutes. Ice massage is more effective at reducing labor pain than acupressure and is simpler, cheaper to do during labor period $^{1}$. Ice gel compress is very useful in reducing labor because it also does not affect the progress of labor. Therefore, ice gel compress is safe to be given to mothers who are in labor so that "love mother" labor care can be achieved and mothers can deliver their baby in more comfortable situation.

\section{CONCLUSION}

There is an effect of giving ice gel compresses with labor pain during the active phase stage I. Ice gel compresses can be one of the non-pharmacological methods to reduce labor pain effectively, efficiently and economically and can be done by midwives and the families members without any special training

\section{REFERENCES}

1. Abdel N, Abd. F. Effect of ice cold massage and acupressure on labor pain and labor duration: A randomized controlled trial. Journal of Natural Sciences Research 2015;5(22):137-143. Available from http://www.iiste.org/Journals/index.php/ JNSR/article/viewFile/27143/27826

2. Asmadi. Tehnik prosedural keperawatan konsep dan aplikasi kebutuhan dasar klien. Jakarta: Salemba Medika; 2009

3. Baker A, Ferguson SA Perceptions of labour pain by mothers and their attending midwives. Journal of Advanced Nursing 2001;35(2):171-9.

4. Bobak L Dasar-dasar keperawatan maternitas. Jakarta: EGC; 2005.

5. Bonewit-West K. Clinical procedures for medical assistants. Elsevier Health Sciences; 2015

6. Creswell JW. (2016). Research design. Pendekatan kualitatif, kuantitatif dan mixed. In: Qudsy SZ, Fawaid A, editors. Yogyakarta: Pustaka Pelajar.

7. Cunningham, Leveno KJ, Bloom SL, et al (2010). Williams Obstetrics. New York: Mc Graw Hill Medical; 2010.

8. Herrera E, Sandoval MC, Camargo DM. (2010). Motor and sensory nerve conduction are affected differently by ice pack. Physical Therapy 2010;90(4): 581-591. Available from http://www. pubfacts.com/fulltex 